\title{
HADRIAN AND THE LIMITS TO POWER
}

\begin{abstract}
Roman emperors were influenced by precedent and by the expectations of various groups in the Roman Empire that followed from precedent. Yet, imperial decisions by individual emperors influenced groups of Romans and changed their expectations of later emperors. This article analyses this process through the lens of the emperor Hadrian. It pays particular attention to Hadrian's accession, and to the consequences that the way in which he came to power had for some of his imperial behaviour, noticeable the ways in which the emperor dealt with the provinces. Both the constraints which Hadrian faced in his early reign because of the context in which he came to power, and the ways in which his mode of reign seems to have shifted expectations of later rulers are reflected in the way the emperor was (numismatically) represented.
\end{abstract}

Keywords: Hadrian, Roman emperorship, Roman provinces, Imperial roles, Imperial representation.

$\mathbf{R}$ oman emperors were sole rulers of their Empire. But even they were not completely free in the way they held their power. Each emperor had to deal with various groups, of which soldiers, senators, the people of Rome, members of the court, and the elite of the provinces were the most important ones. Those groups had expectations about how their rulers had to act, expectations that were determined by precedents from the immediate and more remote past. For that reason alone, the rule of individual Roman emperors and the way they portrayed themselves through coins and other media must always be viewed in the context of the behaviour of their predecessors. ${ }^{1}$

\section{THE BURDEN OF THE PAST}

A case in point is the reign of Hadrian. When he came

\footnotetext{
${ }^{1}$ An earlier Dutch version of this article was published as HEKSTER 2015. Additional research was funded by the Netherlands Organisation for Scientific Research.
}

\section{Olivier Hekster}

Radboud University, Nijmegen

o.hekster@let.ru.n]

DOI: 10.14795/j.v7i1_SI.486

ISSN $2360-266 \mathrm{X}$

ISSN-L 2360 - 266X 
to power in 117 , it was after a rule of almost twenty years by his predecessor Trajan (98117). Trajan was one of the greatest victors in Roman history, who (perhaps because he spent so little time in Rome) had a good relationship with the senatorial elite. Before his reign, there was the brief emperorship of Nerva (96-98), who in turn was the successor to Domitian (81-96) - the last Flavian. Domitian had been a ruler for fifteen years. He became known as a paranoid tyrant, but also initiated a popular building program, brought economic stability and gained (through his general Agricola) important victories in Britain. ${ }^{2}$ Roughly speaking, everyone of twenty-five years of age and younger had only known Trajan as an active ruler, and everyone under forty had mainly experienced Domitian and Trajan as emperors. Only people over forty could remember previous regimes.

That group of people over forty was larger than the average life expectancy in the Roman Empire would suggest. The average age (of twenty five) includes a high infant mortality. Consequently, there was a substantial group of people who were fifty years or older. Thus, out of the 100,000 children who survived the first ten years, around 60,000 would live to the age of forty, around 45,000 to fifty, and some 30,000 would become sixty years old. About 15,000 people of this group would turn seventy, and a good 3,000 even eighty years old. Information from Egypt shows that an arrangement through which people over the age of sixty-two did not have to pay capital tax was regularly made use of. ${ }^{3}$

In all likelihood, the age of the group that was active in the administration of the empire will have been above average. During the imperial period, the official minimum age for the consulate fluctuated between thirty and forty years. Men of utmost importance were rewarded with a second consulate, with

\footnotetext{
2 For the reign of Trajan, see BENNETT 2001 en BIRLEY 2013, 130-138. For the reign of Domitian, see still especially JONES 1992. For the aftermath of Domitian's death, see GRAINGER 2003.

3 PARKIN 2003, 281, table 4 and 5.
}

rarely less than ten years between these two magistrates. Marcus Annius Verus, who was appointed 'consul II' by Hadrian in 121, had already been a consul in 97, and Marcus Lollius Paullinus Valerius Asiaticus Saturninus was 'consul I' in 94 and 'consul II' in 125. 'These two consuls will even have experienced the infamous reign of Nero (54-68) and the subsequent civil wars in the year of the four emperors. A much larger group of senators will have had an active memory of Vespasian (69-79), who had gained a good reputation through his victory in Judea, an ambitious building program in Rome (including the Temple of Peace and the Colosseum), and through his carefully cultivated image of modesty and approachability. ${ }^{5}$ These previous emperors, in turn, would have had to deal with the experience and expectations of the people around them, so that in the almost one hundred and fifty years of emperorship between Augustus and Hadrian an almost canonical set of expectations had arisen, with which any new emperor had to deal. ${ }^{6}$

In this way, historical precedent at the beginning of the second century determined that an emperor had to fulfil a number of roles in order to meet expectations. ${ }^{7}$ Like almost all emperors before him, he had to be a prominent builder in the city of Rome, to compete with the monuments constructed by his predecessors, which included temples, porticos, aqueducts and bathhouses - most prominently the fora of Caesar, Augustus, Vespasian, Domitian / Nerva and Trajan. ${ }^{8}$ In addition, an emperor had to take care of the administration of justice. Domitian, who had appointed himself censor for life, had formally taken on the most important authority on what was deemed to be appropriate behaviour, but other emperors had also been responsible for a range of legal

\footnotetext{
4 PARKIN 2003, 168-9, 282-3, table 6.

5 LEVICK 1999.

6 WALLACE-HADRILL 1981, 298-323 and NOREÑA 2011.

7 This point is made more fully in HEKSTER forthcoming.

8 BOATWRIGHT 1987 and 2000. Cf. ZANKER 1997.
} 
decisions. $^{9}$ The correspondence between Trajan and his governor Pliny the Younger shows how directly an emperor was expected to interfere in decisions. That Hadrian, too, had to deal with this kind of expectations is best illustrated in a well-known passage by the much-later Cassius Dio. It describes how Hadrian was approached by a woman who asked for his attention: '... once, when a woman made a request of him as he passed by on a journey, he at first said to her, "I haven't time", but afterwards, when she cried out, "Stop, then, being emperor", he turned about and granted her a hearing. ${ }^{10}$

The third important role for an emperor was that of a successful general. Rulers without military experience had a problematic power base and there are several examples of rulers who tried to present minor victories as gloriously as possible. ${ }^{11}$ Finally, there were expectations, both in Rome and in the provinces, that a good emperor would pay respect to local elites - with the transgressions of Domitian on this front probably fresh in people's memories.

\section{DIRECT CONTEXT}

Each emperor at the beginning of the second century would have had to relate to the expectations as described above. Hadrian also had to deal with some factors that specifically applied to the years and ways in which he came to power. Hadrian's most immediate problem was the way in which he was declared emperor. That happened on 11 August 117 in Syria, in the direct aftermath of Trajan's death, by the local legions. That in itself was unsurprising. Hadrian was the obvious imperial successor. He was Trajan's closest male relative, and had been married to the emperor's niece Sabina since 100. Between the death of Hadrian's father in 85/86, when Hadrian was nine, and the time when Hadrian, somewhere between

\footnotetext{
${ }_{9}$ MILLAR 1992, 203-272; CORIAT 1997. See now also the various articles in HEKSTER/VERBOVEN 2019.

10 Dio, 69.6.3, with the commentary and parallels in MILLAR 1992, 3-4.

11 On the emperor and his army, see still: CAMPBELL 1984, on representations of war see HÖLSCHER 2004.
}

his fourteenth and seventeenth birthday, received the toga virilis, Trajan even had been one of Hadrian's two guardians. Hadrian had also received important magistracies at a fairly young age, and had played an important military role in Trajan's campaign against the Parthians (114-117). ${ }^{12}$ However, Hadrian had not been formally adopted by Trajan at the time of the latter's death, nor officially declared his successor. A story was circulated that Trajan had appointed Hadrian his heir on his deathbed, in the presence of a limited number of faithful. Yet, it was not Trajan, but his wife Plotina, who signed the letters in which this was made known. ${ }^{13}$

Hadrian seems to have been aware of the precarious situation in which he found himself. According to the Historia Augusta, the new emperor sent a cautious letter to the senate. In it, he 'apologised because he had not left it the right to decide on his accession'. ${ }^{14}$ Unsurprisingly, there was immediate speculation about the legality of the adoption, about whether Trajan still had been alive when Plotina signed the letters, and about the relationship between Hadrian and Plotina.

Coins testify how precarious the situation must have been. Firstly, there is a very rare aureus, which seems to have been struck directly surrounding Trajan's death in Antioch, probably for the legionaries. The reverse which portrays a laureate bust of Hadrian has as legend (Fig. 1) 'for Hadrian Trajan Caesar' (HADRIANi TRAIANO CAESARI), probably to boost the credibility of the adoption. Trajan is depicted on the obverse with a legend that reads 'Imperator Caesar Nerva Traianus, the best Augustus, conqueror of Germany and Dacia'. ${ }^{15}$ The implication of this type would be that Hadrian had been proclaimed by Trajan

\footnotetext{
12 For references to Hadrian's early life: $P I R^{2}$ A 184.

13 Pliny, Letters, 5.12; Aulus Gellius, Attic Nights, 11.15.3; Dio 69, 1.1-4; HA, Hadrian, 4.6, 4.10; BIRLEY 1997, 77-80 with further references and discussion of the ancient sources. See also CLARIDGE 2013, 5-6.

14 HA, Hadrian, 6.1-2

15 BURNETT 2008, with ROMAN/ RÉMY/ RICCARDI 2009 .
} 


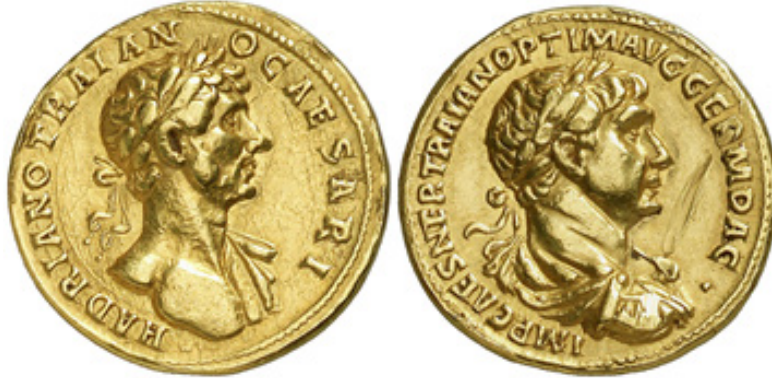

Fig. 1. Aureus, Trajan for Hadrian as Caesar (https://www.acsearch.info/image.html?id=117473)

as 'Caesar' and thus formal successor to the throne. Yet, ancient sources are unambiguous in that Trajan only adopted Hadrian at the very last moment, if at all. There are no good arguments against the coins' authenticity, though the sequence 'Hadrian Trajan' in the legend is odd. Normally the adopted father's name would come first, as it does in later Hadrianic coins. No other Trajanic coin type, furthermore, foreshadows Hadrian's position as Caesar. ${ }^{16}$ It therefore seems unlikely that these coins were still struck during Trajan's life. That would make the coins an equivalent to the letters drawn by Plotina: an attempt to make Hadrian's accession as legitimate as possible.

In the aftermath of Trajan's death, adoption was an important part of Hadrian's early coinage. Yet the issue was only broadcast fairly briefly. For instance, the Reka Devnia hoard of over 80,000 denarii includes almost 6,000 Hadrianic coins. Of those just over 2,000 name Trajan in the obverse nomenclature, but only 152 explicitly refer to Hadrian as TRAIANI FILIUS and a mere 12 combine the sonship with Adoptio. ${ }^{17}$ Whereas almost all coins that were minted in 117 included PARTIC DIVI Traian Avg F P M TR P Cos P P or a variant thereof in the legend, from 118 the association between Trajan was limited to IMP CAESAR TRAIAN HADRIANVS Avg on the obverse. From 124/125 there are no denarii at all that link Hadrian and Trajan, though Divvs TRAIANvs incidentally appears on bronzes and gold coins ${ }^{18} \mathrm{~A}$ brief period of much attention to

\footnotetext{
16 BURNETT 2008, 462-466.

17 The references follow the Reka Devnia hoard as tabulated on https://chre.ashmus.ox.ac.uk/hoard/3406. 18 As can be traced on http://numismatics.org/ocre/.
}

the adoption, followed by relative numismatic silence regarding Hadrian's adopted father reinforces the idea that there was a lot of discussion about the beginning of Hadrian's emperorship, which the new emperor had to react to in his first year of reign.

The direct political context aside, Hadrian also had to deal with the social context of the empire that he had 'inherited'. The actions of his immediate predecessors played a role in this.

The Roman empire, of course, was established through conquests, with members of conquered peoples (especially the elite) granted Roman civil rights from an early stage onwards. As is well known, the process took flight under Caesar and the successive emperors. Famously, the increasingly prominent role of provincials led to the permission of Claudius (41-54) for members of the Gallic elite, who had held Roman citizenship for generations, to become senators.

It took a lot longer before well-known families from the Greek East came into a comparable position. The Romans traditionally respected Greek culture, as clearly stated Horace's famous dictum 'Defeated Greece overcame its savage conqueror'. ${ }^{19}$ But at a moral- political level there were strong prejudices against the Greeks. The result was that under the first emperors, hardly any men from Eastern origin were included in the Senate. This changed under Vespasianus, for two main reasons: during the reign of Nero and the civil war that followed, so many ancient Roman families became extinct that new blood was needed; and Vespasian was proclaimed emperor by troops from the east. Under Domitian, far fewer 'Easterners' became senators. There was a renewed influx under Trajan, probably linked to his wars in the east, which offered the elite in Asia Minor the

Note, also, how coins emphasise some sort of divine election, probably, as already noted by FEARS 1977 , 246 'to minimize the role of his predecessor in his elavation'.

19 Horace, Letters ii.1.156. 
opportunity to show their (military) qualities directly to the emperor. ${ }^{20}$ The upshot of all this was that Hadrian was the first emperor who, from the moment of his accession onwards, had to deal with prominent groups of senators from western and eastern provinces. Representatives from almost all provinces were now at the heart of power.

The provinces were also a relevant context for the start of Hadrian's reign in a different way. During the war against the Parthians, the so-called 'Jewish Diaspora War' (115-117) broke out in large parts of the east. Its consequences would strongly influence Hadrian's twenty-year reign. While most of the Roman legions were in the East with Trajan, groups of Jews in Libya, Cyprus and Egypt rebelled. ${ }^{21}$ Almost a century earlier, the first Jewish revolt (66-70) had been suppressed by Vespasian and Titus. The Temple in Jerusalem was destroyed, and from then onwards Jews had to pay a poll tax to the temple of Jupiter Optimus Maximus in Rome, whereas before they had been allowed to spend that money on maintenance of their own temple.

This Roman victory was of great PR interest to the Flavian emperors, who used it to emphasise their military qualities. Under Nerva, Rome became somewhat less repressive, but under Trajan the hated tax was again strictly collected, and Jews were again explicitly presented as enemies of Rome. This will have led to further frustration. ${ }^{22}$ In 115 or 116 the situation exploded. The uprising quickly took on disturbing forms for Rome. Cassius Dio mentions 220,000 deaths in Cyrenaica, and 240,000 deaths in Cyprus. In Egypt, papyri stop indicating payment of temple tax from May 18, 116, onwards, dating the start of the uprising there very precisely. One surviving papyrus account even states that the insurgents defeated a legion. Only the help of the strongly anti-Jewish Egyptian

\footnotetext{
20 HALFMANN 1979, 71-79; CORTÉS-COPETE 2004.

21 On Roman conduct against the Jews, and the various resulting uprising and wars, see GAMBASH 2015, 144-179. 22 GOODMAN 2007, 468-474. On the Flavian PR campaign, see CODY 2003.
}

population kept the Jews under control until Trajan could send a new legion. 'Many tens of thousands of Jews' are said to have been killed in Egypt, with the need for a coordinated Roman reaction under command of Lusius Quietus to ultimately contain the uprising. ${ }^{23}$

Put briefly, at the beginning of his emperorship, Hadrian had to deal with a precarious political situation. There were doubts about the legitimacy of his position. He was far removed from Rome in a world in which the Emperor was expected to be near Rome, in a military context in which Rome had achieved impressive victories, but also seen great disturbances over an extensive area. Trajan's' glorious campaign against the Parthians increasingly looked like imperial overstretch, with detrimental effects for the Eastern provinces that had been peaceful up to then. Exactly those provinces were better than ever represented in the senate. It seems likely that senators from the East will have insisted on restoring the peace, while others, conditioned by the importance that all previous emperors had attached to victories, must have expected great military deeds from the emperor. A reign could begin in an easier manner.

\section{CONSEQUENCES OF CONTEXT}

Over twenty years of imperial behaviour cannot be fully explained by the situation with which Hadrian was confronted at the beginning of his reign. Yet, that situation undeniably created the framework within which his government had to take shape. The first actions of the new emperor were reactive. Lusius Quietus, who had forcefully crushed the Jewish uprising and had received the command over a great many soldiers in the process, was relieved of his position. In the course of 118 , he would be murdered in unclear circumstances. Hadrian showed his authority. He also removed a general who had become unpopular with many, and was a personification of Trajan's expansionism. It

${ }^{23}$ Corpus Papyrorum Judaicarum 438; BIRLEY 1997, 724, with 324 n. 20. 
will have given the emperor some popularity with the Jews. ${ }^{24}$ Several generals and a number of senators will have been less enthusiastic, especially after other high-ranking Trajanic allies were replaced, in some cases to die in more or less mysterious ways.

Hadrian's best-known action, taken immediately after taking office, was also reactive. The emperor ordered to leave Mesopotamia, Assyria and large parts of Armenia. The Roman Empire was to end at the Euphrates and the Tigris. According to most modern historians, this was inevitable. The new territory that Trajan had conquered could not be defended. In fact, Trajan had already effectively given up parts of the area he had conquered, as a consequence of the Diaspora Uprising and Parthian military actions. In other parts of the empire difficulties arose because of the large concentration of troops in the East, assembled there to fight the Parthians. Furthermore, Hadrian had to return to Rome quickly to consolidate his power. But the necessity of the retreat does not make Hadrian's decision less innovative. Noticeably, he did not even try to present his decision as a victory. To defend his actions, Hadrian is said to have turned to a statement of Cato from 167 BC, who argued that there was no use subduing the Macedonians if they could not be held as subjects. ${ }^{25}$ That Hadrian had to use a Republican precedent to defend his decision is significant. Rome was an expansionist society, and giving up territory went against centuries of expectations. Again, coins can help us understand how the emperor reacted to this context. As mentioned above, soon after taking up power, in 118, the obverse legend on central coinage changed markedly from the lengthy titulature of Trajan to Imp Caesar Traian Hadrianvs Avg. In 125, when Hadrian returned from his first journeys, the legend was reduced even further to HADRIANVs Avgvstvs. ${ }^{26}$ This is often taken

\footnotetext{
${ }^{24}$ HA, Hadrian 5.8; PIR 2 L439; HENGEL 1984/5, 153-160.

25 HA, Hadrian, 5.3 with Livy 45.17-18; Pricianus, Gramm.2.88.9; BIRLEY 1997, 78-88.

26 See above, n. 18.
}

as a reference to Augustan coinage, which it may well have been. Yet, it was also an elegant way to take attention away from the absence of Hadrianic victory titles.

It will not surprise that all of this led to resistance. Hadrian secured his position through the appointments of those loyal to him at important positions, as mentioned above, and through the elimination of potential competitors. This put severe strains on the relationship between emperor and senators. Especially the execution of four exconsuls at the beginning of 118 , in response to an alleged attack, led to more antagonism from senatorial circles than Trajan had ever experienced. ${ }^{27}$ Perhaps Hadrian could have acted differently here. Still, the problematic relationship between emperor and senators and the emperor's need to show himself a good military leader to his soldiers appear to be direct consequences of the context in which Hadrian came to power.

\section{EMPEROR AS THE CENTRE OF THE WORLD}

Some of the most striking elements of Hadrian's emperorship, it seems, can be at least in part explained from the initial situation of his reign. An emperor who did not play the military role had to move quickly to Rome, to emphasise his position as an approachable patron. Once there, he started the construction of the massive temple for Venus and Roma, which in many ways can be interpreted as 'Hadrian's Forum'. ${ }^{28}$ The difficult relationship with Roman senators will have played an important part in Hadrian's decision to travel through the provinces for much of his reign, and to then settle outside Rome in his large villa at Tivoli.

Those same journeys also allowed Hadrian to show himself to his troops. It is insufficiently noted that during the course of his travels the emperor systematically visited legion after legion, held strong speeches about military discipline there, and highlighted

\footnotetext{
27 SYME 1958, 485, 599-602.

28 MOLS 2003.
} 
the tough military way in which he travelled. Not coincidentally, centrally designed coins and statues often portray Hadrian in army equipment. A recent analysis of imperial statuary shows that there is a substantial increase in military-styled images that starts under Hadrian, who is almost exclusively depicted in a military mode. Out of the 53 portraits of the emperor that can be directly linked to the body of the statue, 46 emphasise the emperor in his military role. ${ }^{29}$ Moreover, under Hadrian a new type of numismatic portrait was introduced, which combined the cuirassed bust with a paludamentum. Hadrian appears in cuirass on the obverse of approximately 500 types in the Reka Devnia hoard, with substantial numbers of reverse types showing belligerent themes, such as a cuirassed Roma or Hercules suited on a cuirass. ${ }^{30}$ By being personally present with his soldiers and by being represented as general on images, the emperor found a way to show his necessary military qualities.

In addition, the journeys allowed Hadrian to directly play his role in the administration of justice in the provinces. This imperial role was, on the whole, underrepresented in visual media, with the reign of Hadrian as one of the few exceptions. Thus, almost $75 \%$ of coin types and of coins found in assembled hoards issued in the first three centuries of the empire that referred to iustitia were struck under Hadrian. ${ }^{31}$ Similarly, the only extant images of a togate emperor on a curule chair depicted on provincial coinage

${ }^{29}$ Hadrian addressing the troops: CIL 3.3676 (= ILS 2558); CIL 8.2532 and 18042 (= ILS 2487 and 9133-5); RIC II, p. 267 nos. 322-323. The statuary is discussed in HEIJNEN, forthcoming. Cf. KARANASTASI 2013

30 https://chre.ashmus.ox.ac.uk/hoard/3406. Hadrian is depicted togate on only 60 reverse types in the Reka Devnia hoard. On the new portrait type: BASTIEN 1992, 248, 257, figs. 28-29. I owe this reference to Sam Heijnen.

31 As found through queries in the OCRE website (http://numismatics.org/ocre/). The analysis of bronze coins from hoards shows that 99 out of 140 coins were minted under Hadrian: NOREÑA 2011, 349. For the relative lack of imperial justice images, see HEKSTER, forthcoming. show Hadrian. ${ }^{32}$ It is tempting to link this rise to Hadrian's many travels, making him visible to a larger group of subjects, during the course of which he is likely often to have been approached to give his judgement. Hadrian also played an important role in the harmonization of Roman law, and with his visits and many letters intervened directly in

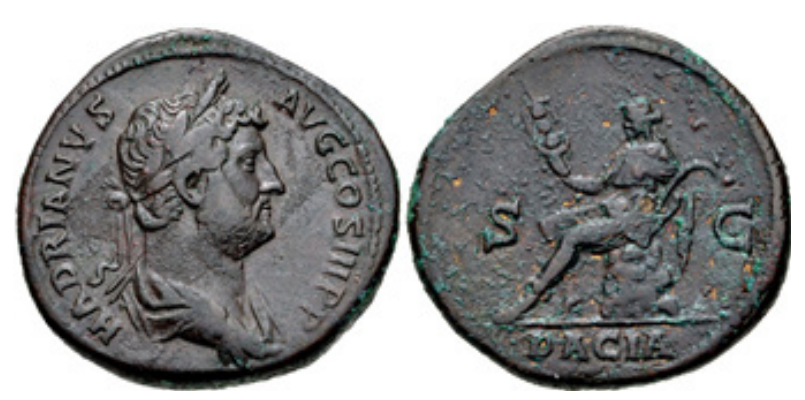

Fig. 2. As, Hadrian: DACIA

(https://www.acsearch.info/image.html?id=3287041)

legal affairs throughout the empire. ${ }^{33}$

This increased emphasis on the emperor as lawgiver and ultimate judge took place at a time in which, as mentioned above, the provincial elite was playing an increasingly important role in the empire. Consequently, the imperial dependence on the Roman elite must have decreased which considering Hadrian's troubled relationship with senators will have been an additional advantage. This may be linked to the highly innovative way in which provinces were depicted on central coins in the years 134-137 (Figs. 2-3): they were no longer shown as conquered territory but as independent, iconographically recognizable, personifications, like the 300 reverse coins in the Reka Devnia hoard, showing especially Aegyptos (including Nilus), Africa and Asia. ${ }^{34}$

32 http://rpc.ashmus.ox.ac.uk/, with 'curule chair' as search term. Out of almost 30,000 coin types for the years AD 96-192, 222-244 and 249-254, only fifty show a curule chair, and only twenty of those show an emperor seated on that chair. The Hadrianic coins (one in bronze and one in silver) are vol III, nos. 5167 and 5260 .

33 CORTÉS-COPETE 2017; HONORÉ 1994, 1216. Hadrian was also named nomothetes on public monuments of Cyrene (SEG 17.809) and Megara (IC VII.70-2); BOATWRIGHT 2000, 91-92.

34 VITALE 2017, 112-118, with https://chre.ashmus. ox.ac.uk/hoard/3406. But note that there are over 500 

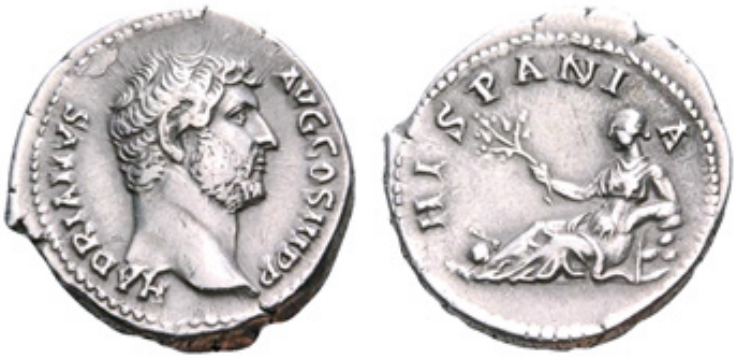

Fig. 3. Denarius, Hadrian: HISPANIA

(https://www.acsearch.info/image.html?id=1845024)
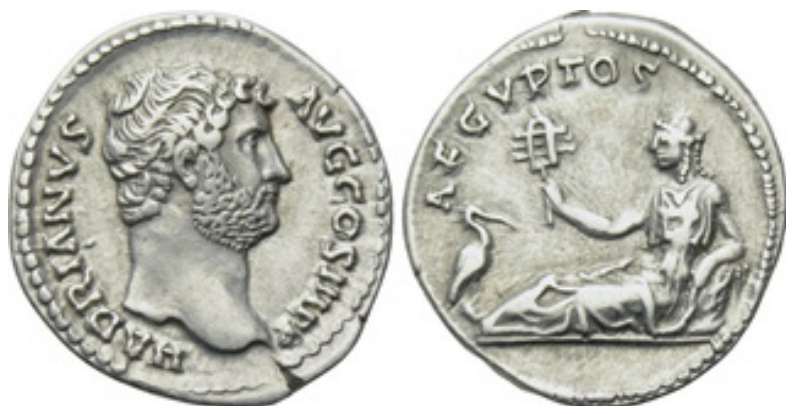

Fig. 4. Denarius, Hadrian : AEGYPTOS

(https://www.acsearch.info/image.html?id=2200686)
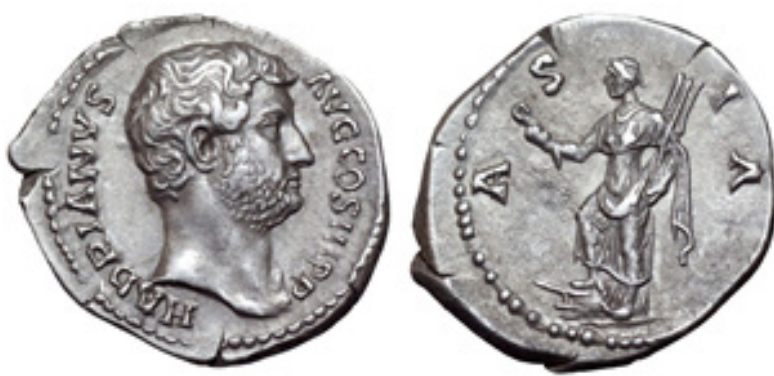

Fig. 5. Denarius, Hadrian: ASIA

(https://www.acsearch.info/image.html?id=3350118)

The emphatic role for the provinces during Hadrian reign made him popular in those provinces. Cities outside the Italian peninsula erected more statues for Hadrian than for any other Roman ruler. There are 418 remaining statue bases for Hadrian, $60 \%$ of which are from the east. The relatively high number of bases for posthumous statues (18) testifies to the continued popularity of Hadrian in his empire. Most of these statues were erected by cities which had been helped by the emperor during his travels. ${ }^{35}$

An additional consequence of the

coins showing Roma.

35 HØJTE 2005, 137, 638 C.12, 642 C.19-20; DEPPMEYER 2008, I, 50.

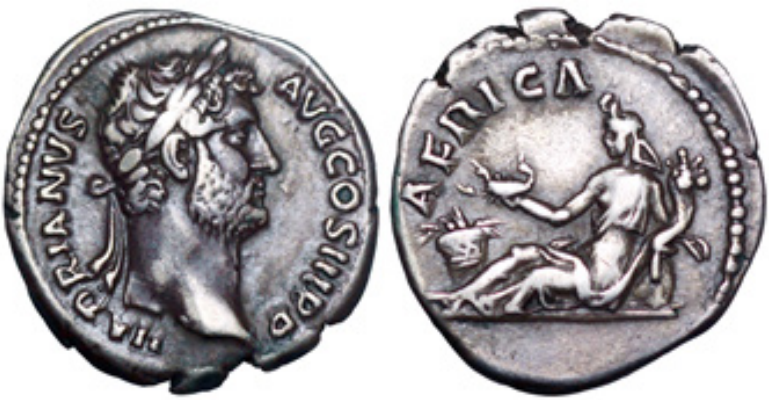

Fig. 6. Denarius, Hadrian: AFRICA

(https://www.acsearch.info/image.html?id=1702623)
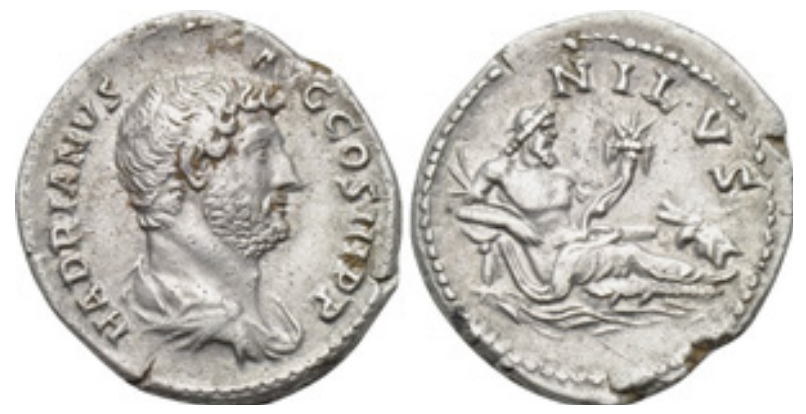

Fig. 7. Denarius, Hadrian:

NILVS (https://www.acsearch.info/image.html?id=2078565)

many imperial journeys and of the many monuments built in the provinces was a reduction of the difference in status between Rome and the rest of the empire. It would take another almost two centuries before it could be suggested that 'Rome is where the Emperor is', but Hadrian seems to have taken first steps in that direction. His choice to live in Tivoli, and not in Rome after returning to the Italian mainland is telling. His villa, after all, was a miniature world in which Rome literally became background. ${ }^{36}$

Of course, one cannot simply see this Hadrianic shift towards a 'universal' rule that was less Rome-dependent as an inevitable consequence of the context in which Hadrian had taken power. The individual choices of emperors also played a large role in the way they held their power. Hadrian's love for the Greek world, for instance, demonstrably goes back to well before he became emperor. This affection that was not uncommon for Roman elite men, especially not at the beginning of the

36 Panegyrici Latini 11 (3), 2.4, 8.1, 11.3-4, 12.2. On Hardian's Villa: CHARLES-GAFFIOT/ LAVAGNE 1999; GROS 2002. 
second century. ${ }^{37}$ Still, it remains remarkable that when Hadrian visited Athens in 112, he chose to take up a prominent magistracy (as an archon). ${ }^{38}$ That must have been the emperor's individual choice, more than a consequence of context.

These kinds of personal choices and preferences play important roles in historical developments. Thus, Hadrian's 'cultural politics' and his attempts at panhellenism were (at least indirectly) the impetus for a renewed Jewish revolt. This so-called Bar Kochba war (132-5) lead to such military difficulties that Hadrian, against all precedent, for a while did not start his letters to senators with the traditional sentence 'with me and my legions all is well'. The ultimate suppression of this war on Roman soil could not really be presented as a victory. It was hardly commemorated in Rome, although a triumphal arch was erected in Judea to emphasise Roman superiority. ${ }^{39}$ Where the Diaspora rebellion determined the context in which Hadrian took power, Hadrian determined the context in which the Bar Kochba revolt began. ${ }^{40}$

An emperor was influenced by precedent and by the expectations of various groups in the Roman Empire that followed from precedent. His individual decisions, in turn, would influence groups of Romans and their expectations for later emperors. Hadrian must be viewed in the context of his time, in turn creating the context for his successors.

\footnotetext{
37 Zanker 1995, 213. For the complicated (power) relationship between Greeks and Romans in the earlysecond century, see still esp. SWAIN 1996.

${ }^{38}$ CIL 3, $550=$ ILS 308, with Salomies 2001, 89.

39 ECK 1999, 76-89.

40 Direct influence is also suggested by an inscription that was found in October 2014, showing the right half of a text of which, the left half had been known since the $19^{\text {th }}$ century. Reconstruction and translation of the text was by Avner Ecker and Hannah Cotton. The combination of imperial titles and the name of the legion which initiated the inscription (the $10^{\text {th }}$ legion Fretensis Antoniniana) suggests that Hadrian was in Jerusalem in 129/130, and that his acts there were an important element in the start of the revolt: https:// www.archaeology.wiki/blog/2014/10/22/imperatorcaesar-traianus-hadrianus-augustus
}

\section{REFERENCES}

BASTIEN 1992

Bastien, P.: Le buste monétaire des empereurs romains. I. Numismatique Romaine: Essais, Recherches et Documents (Wetteren)

\section{BENNETT 2001}

Bennett, J.: Trajan: Optimus Princeps: A life and times (Bloomington: Indiana University Press)

\section{BIRLEY 2013}

Birley, A.R.: 'Britain under Trajan and Hadrian'. In T. Oppen (ed.), Hadrian: art, politics and economy, 130-138 (London).

\section{BIRLEY 1997}

Birley, A.R.: Hadrian. The restless emperor (Londen - New York).

\section{BOATWRIGHT 1987}

Boatwright, M.T.: Hadrian and the city of Rome (Princeton).

BOATWRIGHT 2000

Boatwright, M.T.: Hadrian and the cities of the Roman empire (Princeton).

\section{SALOMIES 2001}

Salomies, O.: 'Names and identities: onomastics and prosopography'. In J. Bodel (ed), Epigraphic Evidence: Ancient History from Inscriptions, 73-95 (London - New York) BURNETT 2008

Burnett, A.: 'The early coinage of Hadrian and the deified Trajan at Rome and Alexandria', AJN 20, 459-477.

\section{CAMPBELL 1984}

Campbell, J. B.: The Emperor and the Roman Army. 31 BC-AD 235 (Oxford).

\section{CHARLES-GAFFIOT/ LAVAGNE 1999}

Charles-Gaffiot, J./ Lavagne, H.: Hadrien.

Trésors d'une villa imperial (Milan).

\section{CLARIDGE 2013}

Claridge, A.: 'Hadrian's succession and the monuments of Trajan'. In: T. Opper (ed.), Hadrian: Art, Politics and Economy, 5-18 (Londen).

\section{CODY 2003}

Cody, J.M.: 'Conquerors and conquered on Flavian coins'. In: A.J.Boyle/ W.J.Dominik (eds.), Flavian Rome. Culture, Image, Text, 103-123 (Leiden - Boston). 


\section{CORIAT 1997}

Coriat, J.-P.: Le prince législateur (Rome). CORTÉS-COPETE 2004

Cortés-Copete, J.M.: 'Un nuevo gobierno, una nueva base social'. In: J.M. Cortés Copete/ E. Muñiz Grijalvo (eds), Adriano Augusto, 73-86 (Sevilla).

CORTÉS-COPETE 2017

Cortés-Copete, J.M.: 'Governing by Dispatching Letters. The Hadrianic Chancellery’. In: C. Rosillo-López (ed.), Political Communication in the Roman World, 107136 (Boston - Leiden).

\section{DEPPMEYER 2008}

Deppmeyer,K.:KaisergruppenvonVespasian bis Konstantin. Eine Untersuchung zu Aufstellungskontexten und Intentionen der statuarische Präsentation kaiserlichen Familien (Hamburg).

ECK 1999

Eck, W.: 'The Bar Kokhba Revolt: the Roman point of view', Journal of Roman Studies 89, 76-89.

FEARS 1977

Fears, R.: Princeps a Diis Electus. The Divine Election of the Emperor as a Political Concept at Rome (Rome)

GAMBASH 2015

Gambash, G.: Rome and Provincial Resistance (New York - London).

GOODMAN 2007

Goodman, M.: Rome and Jerusalem. The Clash of Ancient Civilizations (Londen).

GRAINGER 2003

Grainger, J.D.: Nerva and the Roman succession crisis of AD 96-99 (Londen New York).

GROS 2002

Gros, P.: 'Hadrien architecte. Bilan des recherches'. In: M. Mosser/ H. Lavagne, Hadrien empereur et architecte. La Villa d'Hadrien: tradition et modernité d'un paysage culturel, 33-53 (Geneva).

\section{HALFMANN 1979}

Halfmann, H.: Die Senatoren aus dem östlichen Teil des Imperiums Romanum bis zum Ende des 2. Jahrhunderts n. Chr. (Göttingen)

\section{HEIJNEN, FORTHCOMING}

Heijnen, S.: 'Living up to expectations: Hadrian's military representation in freestanding sculpture', BABESCH 95

\section{HEKSTER 2015}

Hekster, O.: 'Hadrianus en de grenzen aan de macht'. In: O. Hekster/ C. Jansen (eds.), De wereld van Hadrianus, 31-43 (Nijmegen).

\section{HEKSTER/VERBOVEN 2019}

Hekster, O./ Verboven, K. (eds): The Impact of Justice on the Roman Empire (Leiden Boston).

\section{HEKSTER forthcoming}

Hekster, O.: 'Les contraintes posées par la tradition dans la création de l'image impériale'. In : P. Ledoze (ed), Le costume de Prince. Regards sur une figure politique de la Rome antique d'Auguste à Constantin (Rome).

\section{HENGEL 1984/5}

Hengel, M.: 'Hadrians Politik gegenüber Juden und Christen', Journal of the Ancient Near East Society 16/17, 153-182.

HØJTE 2005

Højte, J.M.: Roman Imperial Statue Bases. From Augustus to Commodus (Aarhus) HÖLSCHER 2004

Hölscher, T.: 'Images of war in Greece and Rome: between military practice, public memory and cultural symbolism', JRS 94, 1-17.

\section{HONORÉ 1994}

Honoré, T.: Emperors and Lawyers (Oxford, $2^{\text {nd }}$ edition).

\section{JONES 1992}

Jones, B.W.: The Emperor Domitian (Londen - New York)

\section{KARANASTASI 2012}

Karanastasi, P.: 'Hadrian im Panzer: Kaiserstatuen zwischen Realpolitik und Philhellenismus', Jahrbuch des Deutschen Archäologischen Instituts 127/128, 323391.

\section{LEVICK 1999}

Levick, B.: Vespasian (Londen - New York). MILLAR 1992

Millar, F.G.B.: The Emperor in the Roman World, 31 BC - AD 337 (London, $2^{\text {nd }}$ edition). 


\section{MOLS 2003}

Mols, S.T.A.M.: 'The cult of Roma Aeterna in Hadrian's politics'. In L. de Blois et al. (eds), The Representation and Perception of Roman Imperial Power, 458-465 (Amsterdam).

NOREÑA 2011

Noreña, C.: Imperial Ideals in the Roman West: Representation, Circulation, Power (Cambridge ).

PARKIN 2003

PARKIN, T.G.: Old Age in the Roman world.

A Cultural and Social History (Baltimore Londen).

ROMAN/ RÉMY/ RICCARDI 2009

Roman. Y./ Rémy, B./ Riccardi, L.: 'Les intrigues de Plotine et la succession de Trajan

à propos d'un aureus au nom d'Hadrien César', Revue des Etudes Anciennes 11 , 508-17.

\section{SWAIN 1996}

Swain, S.: Hellenism and Empire: Language, Classicism and Power in the Greek World AD 50-250 (Oxford).

\section{SYME 1958}

Syme, R. Tacitus (Oxford).

\section{VITALE 2017}

Vitale, M.: Das Imperium in Wort und Bild. Römische Darstellungsformen beherrschter Gebiete in Inschriftenmonumenten, Münzprägungen und Literatur (Stuttgart)

WALLACE HADRILL 1981

Wallace Hadrill, A.: 'The emperor and his virtues', Historia 30 , 298-323.

\section{ZANKER 1995}

Zanker, P. Die Maske des Sokrates und das Bild des Intellektuellen in der antiken Kunst (Munich)

ZANKER 1997

Zanker, P. Der Kaiser bauts fürs Volk (Wiesbaden) 
